\section{Follow-up and Help Your Neighbours}

\author{
Dr. Lennart Hasselgren describes Uppsala University's unique, \\ government sponsored programme for supporting Third World \\ research in the physical sciences.
}

Sri Lanka and Peru will have their first home-grown doctorates in physics awarded this year to members of groups supported by Sweden's International Program in the Physical Sciences (IPPS) based at Uppsala University. The IPPS has grown in 30 years from modest beginnings as the University's fairly conventional fellowship scheme for visiting scientists from underdeveloped countries, to a multifaceted programme considered by UN experts to be unique in its field.

\section{Follow-up Support}

Aside from supporting researchers via sandwich-type graduate courses and traditional fellowships, the IPPS has pioneered long-term follow-up support to more advanced research groups in the third world. Hearkening Professor Kergries's thoughts (see Letter to the Editor, page $119)$, the aim of this support is to build up a research capacity that encourages scientists being trained in Sweden, and recently to a limited extent in other Nordic countries, to return home. In 1988/89 it accounted for $28 \%$ of funds distributed, as compared to $26 \%$ for fellowships (including allowances), $18 \%$ for traveling expenses for participants, and $16 \%$ for staff salaries and travel costs.

In the Sri Lankan case, cooperation with the Physics Department at the University of Colombo started in the usual way, after thorough on-site discussions, with the signing of a Memorandum of Understanding spelling out the general framework of a 3-5 year cooperation, and the partners' contributions, so that there would be no nasty surprises later on. The essential conditions for any cooperation remain as follows: the active partner must usually be a reasonably mature, advanced group working in experimental aspects of physical sciences in the broadest sense, or judged as having the possibility to develop into such a group; the group itself ought to propose the research project, which should be in line with the country's overall objectives and capable of being adequately staffed.

One of the first Sri Lankan Ph.D's will be awarded to a member of a team specializing in physics of the lower atmosphere a high-priority area because production from an entire tea plantation can be wiped out for a year by a single hail storm. In addition to Fellowships and grants for sandwich courses in Scandinavian institutions, the IPPS provided funds for follow-up support in the form of small items of equipment, literature, workshops, etc.

The IPPS funds a second group in the same department working on molecular desorption, as well as a solid state physics group in the Department of Physics, Uni- versity of Peradeniya. The latter will also be awarding a Ph.D. this year - in this case for research related to solid electrolytes. In all the Sri Lankan cooperations, support has been given to research activities starting from scratch.

The Peruvian first involves selective thin film solar energy collectors - another research field crucial to third world development. Collaboration with seven members of the staff of the National University for Engineering in Lima started in 1982. In this case the University was already rather well equipped for preparing and characterizing thin films so most of the IPPS support went to transferring researchers in both directions - between Peru and Sweden.

\section{Resources}

Literally circling the globe does not imply, however, that the IPPS is all embracing. The annual operating budget of \$US 0.9 million for 1990/91 means that support is concentrated to a maximum of \$US 20-25 k per year on each of about 50 projects in 17 countries in Asia, Africa and South America. A few important cofinancing arrangements with the Third World Academy of Sciences, ITCP, Trieste and with the International Atomic Energy Agency, Vienna have provided useful additional funds for the so-called North-South collaborations.

The Swedish Agency for Research Cooperation with Developing Countries (SAREC for short) is the main contributor to IPPS along with UNESCO labout \$US 4000 ) and the Norwegian Government, whose decision to contribute about \$US 70000 for fiscal year 1989/90 heralds greater participation by other Nordic countries.

\section{Direct Grants and Networking}

Important grants to develop Third World research facilities have also been obtained from SAREC for some countries which cooperate directly with the agency. A good example is the network scheme for solar energy research in Tanzania. It also illustrates another form of cooperation that is being actively promoted by the IPPS. The basic concept is to develop regional centres accessible to researchers in surrounding countries via so-called South-South collaboration.

Based upon a solar energy research group in the Physics Department at the University of Dar-es-Salam, the Tanzanian institute is responsible for handling an IPPS grant for regional institute-institute cooperation. Graduate students are transferred from five neighbouring and nearby countries to a well-equipped laboratory, set up in the Department to prepare and characterize thin films with the help of grants from SAREC totaling nearly \$US $400 \mathrm{k}$.

The overall structure of this regional network collaboration was mapped out at the "Planning Network Projects in Materials Science and Solar Energy" workshop organized in Nairobi by the EPS Interdivisional Group on Physics for Development in November 1988 (see Europhysics News 20 (1989) 111). A follow-on workshop, organized this time by the Dar-es-Salam institute, is being planned.

Grants for regional cooperation totalled $9 \%$ of distributed funds in 1989 , a percentage that will increase as the IPPS budget increases to \$US 1.2 million in 1991.

Administered by a small staff at the University of Uppsala, the IPPS has clearly matured into a well thought out, comprehensive programme to develop research capacities in the third world. Meanwhile, let us not forget the staff's very valuable work acting as hosts to visitors - and to some of the nearly 300 students involved in the various collaborations while they spend time training and carrying out research in Scandinavian institutions.

For further information contact:

Dr. Lennart Hasselgren, Director, IPPS, Box 530, S-751 21 Uppsala, Sweden.

Tel.: $++46-18-183575$;

Fax: $++46-18-183495$;

Telex: $76047 \mathrm{~s}$

\section{La Faculté des Sciences, Université de Genève,}

ouvre une inscription pour un poste de

\section{professeur ordinaire d'astrophysique stellaire}

Charge: II s'agit d'un poste à charge complète, comprenant 6 heures de cours, séminaires, travaux pratiques. Enseignement en français aux différents cycles d'études universitaires et au grand public.

Direction d'un groupe de recherche et responsabilité d'établissement de programmes d'observation dans le domaine de la physique stellaire. Une expérience dans les phénomènes de variabilité est souhaitée.

Titre exigé: Doctorat ou titre jugé équivalent.

Entrée en fonction: 1er octobre 1991 ou date à convenir.

Les dossiers de candidatures doivent être adressés avant le 7 août 1990 au Secrétariat de la Faculté des Sciences, 20 quai Ernest-Ansermet, 1211 Genève 4, auprès duquel des renseignements complémentaires peuvent être obtenus sur le cahier des charges et les conditions. 